\title{
Does emigration reduce corruption?
}

\author{
Artjoms Ivlevs ${ }^{1,2} \cdot$ Roswitha M. King ${ }^{3}$
}

Received: 25 August 2016/Accepted: 3 March 2017/Published online: 20 March 2017

(C) The Author(s) 2017. This article is an open access publication

\begin{abstract}
We study the effects of emigration on bribery experience and attitudes towards corruption in the migrants' countries of origin. Using data from the Gallup Balkan Monitor survey and instrumental variable analysis, we find that having relatives abroad reduces the likelihood of bribing public officials, renders bribe-taking behavior by public officials less acceptable, and reduces the likelihood of being asked for bribes by public officials. Receiving monetary remittances does not change the beneficial effects regarding bribe paying and attitudes toward corruption; however, remittances counteract the beneficial effect on bribe solicitations by public officials. Overall, our findings support the conjecture that migration contributes to the transfer of norms and practices from destination to source countries.
\end{abstract}

Keywords Emigration - Corruption - Diaspora externalities · Social remittances - Western Balkans

JEL Classification F22 $\cdot$ F24 $\cdot$ D73

Electronic supplementary material The online version of this article (doi:10.1007/s11127-017-0442-z) contains supplementary material, which is available to authorized users.

Artjoms Ivlevs

a.ivlevs@uwe.ac.uk

Roswitha M. King

roswitha.m.king@hiof.no

1 Department of Accounting, Economics and Finance, Bristol Business School, University of the West of England, Bristol BS16 1QY, UK

2 IZA, Bristol, UK

3 Department of Economics, Østfold University College, 1757 Halden, Norway 


\section{Introduction}

Migration and corruption are among the defining issues of socioeconomic development across the world. Migration provides a lifeline and offers safety to millions, while corruption remains one of the most pernicious obstacles to economic and social development. ${ }^{1}$ Fighting corruption and managing migration have become major preoccupations of governments across countries at all stages of development. Given the salience of both migration and corruption and the myriad of policy efforts directed toward each of them, it is surprising how little is known about the linkages between the two. Among the underexplored questions are some rather fundamental ones, for example: Does migration augment or reduce corruption in the migration-sending country? It is the focus of this paper.

Specifically, we ask whether emigration of family members and close friends has an effect on bribery experience and attitudes toward corruption of those staying behind. Theoretically, one can conceive of several channels through which migration, as well as remittances, might affect the corruption experiences of those staying behind. Consistent with the migrant value transfer hypothesis (Levitt 1998), migrants who work in a country where corruption is less prevalent than in the country of origin may transfer good practices directly from the host country to family members back home, with subsequent reductions in corrupt practices. However, migrant relatives, and especially those receiving monetary remittances, may also become prime targets for bribe solicitation by public officialsbecause of the larger financial resources with which people with migration connections are associated. This may lead to an increase in the incidence of corrupt practices. Offers to bribe may also come from the remittance receivers - they bribe because they can afford it.

Empirically, one of the main challenges of determining the effect of migration on corruption is the potential endogeneity of migration. It could be explained by reverse causality, as corruption may push people to go abroad (Dimant et al. 2013; Poprawe 2015; Schneider 2015). In addition, unobserved characteristics of people (and/or households) may exist that are correlated with both their willingness to migrate and the propensity to bribe public officials. To deal with endogeneity, we conduct instrumental variable analysis wherein out-migration is predicted by economic conditions in migrant destination countries interacted with historical, local-level migrant networks there. Our findings suggest that migration reduces bribery as well as the acceptability of corruption among those staying behind in the migrant source countries.

This paper advances scholarly discourse in several ways. First, it contributes to the nascent literature exploring the ways through which migration and remittances may affect corruption at home. ${ }^{2}$ While a few studies have provided evidence at the country or region level (Abdih et al. 2012; Beine and Sekkat 2013; Berdiev et al. 2013; Tyburski 2012), to the best of our knowledge only one study has provided household-level evidence on this question: Höckel et al. (2015) find that migrant households are less likely to make informal payments to teachers in Moldova. While our conclusions are in congruence with Höckel et al. (2015), we expand the exploration of the corruption-migration link at the household

\footnotetext{
1 See, for example, Bologna and Ross (2015), Johnson et al. (2011) and (Méon and Sekkat 2005) for the detrimental effects of corruption on entrepreneurship and economic growth. That said, evidence exists that corruption might be 'greasing the wheels' of an economy (e.g., Bologna and Ross 2015; Dreher and Gassebner 2013).

2 More broadly, the paper contributes to a burgeoning literature on 'diaspora externalities' - the effects of emigration on the political, institutional and social outcomes in the migrants' countries of origin (Batista and Vicente 2011; Barsbai et al. 2017; Bertoli and Marchetta 2015; Beine et al. 2013; Chauvet and Mercier 2014; Docquier et al. 2016; Li et al. 2017; Pfutze 2012).
} 
level by considering a wider range of public officials as potential bribe takers, making a distinction between migration with and without monetary remittances, and considering attitudes toward corruption as well as actual bribery experiences. Second, we focus our study on the Western Balkan countries, a region with a long and complex migration history, the consequences of which are not well understood. Also known for having some of the worst corruption profiles in Europe, that region is well suited for our analysis of the nexus between migration and corruption. Third, we use a dataset from the Gallup Balkan Monitor, a rich and underexplored dataset, which allows a nuanced pursuit of our research question in a multi-country setting.

The paper proceeds as follows. Section 2 reviews the relevant literature and discusses channels through which migration may affect corruption at home. Section 3 describes the context. Section 4 presents our data, variables and estimation strategy. Section 5 reports and discusses the results, followed by a conclusion.

\section{Emigration and corruption: Theoretical channels and related literature}

One can conceive of several channels through which emigration may affect corruption at home. First, Hirschman's 'exit and voice' approach (Hirschman 1970) has often been used to explain the institutional effects of migration at the country level (see, e.g., Li et al. 2017). According to this framework, migration can be viewed as an 'exit' option for people dissatisfied with their current situations at home. If more entrepreneurial and activist people constitute a large share of the migrants, their 'exit' will result in less pressure and 'voice' exerted against the ruling authorities. This will lead to weaker institutions and governance in the country of origin; corruption would thus be expected to increase with emigration.

However, migrants do not completely 'exit' their countries of origin. Falling communication and transportation costs allow migrants to develop and maintain transnational spaces and communities, and participate in the social, economic and political life both at home and abroad. In this context, initial migrant 'exit' can strengthen 'loyalty' —emotional attachment to the home country - and empower 'voice', encouraging migrants to bring influence to bear on the political and institutional processes in their country of origin (Burgess 2012). Hoffmann (2010) argues that the externalized 'voice' of the diaspora returns to the home country in an internationalized form and has a stronger political impact than even domestic opposition. Indeed, migrant diasporas are known to have influenced political processes in their countries of origin successfully, at times playing major roles in processes of independence, statehood and democratic reform (Shain and Barth 2003; Hladnik 2009; Phillips 2012). Seen from this perspective, emigration has a potential to bring about political change and improvements in governance, ${ }^{3}$ including better control of corruption. Beine and Sekkat (2013) support this positive 'diaspora externality' conjecture, finding that emigration, and especially high-skilled emigration, has a positive impact on

\footnotetext{
3 This said, the ruling authorities may be well aware of the threat of challenges to the status quo by the internationally empowered migrant 'voice' and design emigration policies accordingly. Taking a historical example, in the Kingdom of Serbs, Croats and Slovenes of the 1920s, an influential emigration policy proposal towards the pro-Bulgarian Macedonian minority (Bulgarophiles) was as follows: "If the Bulgarophiles' organization is more vigorous in America than here, it is better to keep them at home and vice versa" (Miletic 2009, p. 110).
} 
several measures of institutional quality in the sending country, such as "government effectiveness", "regulatory quality" and, crucially for our study, "control of corruption". 4

Next, while diasporas can influence home-country political processes intentionally and directly, migrants also can unintentionally, and without any political agenda, transfer social and institutional norms and practices to their family members back home. In her seminal work, Levitt (1998) defines 'social remittances' as "ideas, practices, identities and social capital" that migrants internalize in countries of destination and transmit to their countries of origin. Levitt shows that emigration experience changes people as they absorb and internalize behavioral norms, value judgements and institutional arrangements in their attempts to prosper in the host country. Through correspondence, visits and return migration, emigrants transmit these intangibles, exerting considerable influence on home country processes, aided by their status as role models. Levitt (1998) finds that migrants transfer notions of gender identity and intra-family responsibility, principles of community participation and norms about the work of clergy, judges and politicians.

Levitt's 'social remittances' represent one possible channel through which migration might affect norms and behaviors among family members staying behind, including, and of central interest for this study, norms and behaviors concerning corruption. Depending on whether corruption is more prevalent at home or abroad, migrants can transfer back home better or worse institutional practices and reduce or increase corruption in their countries of origin. Furthermore, this value transfer effect can be either reinforced or weakened by monetary remittances. On the one hand, remittances can imply closer links and more frequent communication between migrants and their family members back home, making value transfer more effective (communication effect). Remittance senders may also be particularly successful in influencing the behaviors and norms of those left behind as the livelihoods of the latter depend on the money sent from abroad. For example, migrants could threaten to stop sending monetary remittances if they think that family members are reluctant to adopt new anti-corruption-related norms and behavior and/or waste remitted money in bribes (conditionality effect). The transfer of norms in this case can be explicit (remittance recipients internalize new corruption norms) or implicit (remittance recipients stop paying bribes because they are afraid of losing income supplements from abroad rather than because they internalize new corruption norms). ${ }^{5}$

On the other hand, an income effect can be at work. It is possible that remittances increase both the demand for public services (if remittances are used to start new businesses, buy property, enroll in education, undergo treatment in the hospital - all of which may require more frequent contact with public officials) and the probability of bribery once the contact with public officials has taken place (public officials solicit bribes from remittance receivers or remittance receivers are more willing and able to pay bribes to get higher-quality services quicker). As a result, remittance receivers will be more likely to bribe. This conjecture corroborates the prediction of the theoretical model of Höckel et al. (2015), whereby people will make informal payments to teachers to improve their

\footnotetext{
4 In a somewhat different vein, Mariani (2007) argues that the prospect of emigration makes skilled people choose careers related to productive activities (such as entrepreneurship) rather than rent-seeking, corruption-prone activities (such as bureaucracy); this is because productive activities are valued abroad more than rent-seeking is. Such change in the allocation of skilled workers, induced by emigration prospects, would reduce corruption in the home country.

5 Also, migrants may wish family members to change their behavior, but the home country environment may not allow for an easy behavioral change. If migrants understand that fact and continue sending remittances, the conditionality effect and value transfer more generally may not work. See Varese (2011) for a related argument on the willingness versus opportunity to transfer particular types of behavior.
} 
Table 1 The effects of emigration on corruption outcomes of household members staying behind: summary of channels

\begin{tabular}{ll}
\hline Channel & Direction of effect \\
\hline Value transfer & $\begin{array}{c}\text { Less or more corruption, depending on whether corruption is more } \\
\text { prevalent abroad or at home }\end{array}$ \\
$\begin{array}{l}\text { Communication effect through } \\
\text { remittances }\end{array}$ & Amplifies the value transfer channel \\
$\begin{array}{l}\text { Conditionality effect through } \\
\text { remittances }\end{array}$ & Amplifies the value transfer channel \\
$\begin{array}{l}\text { Income effect through } \\
\text { remittances }\end{array}$ & More corruption \\
$\begin{array}{l}\text { Substitution effect through } \\
\text { remittances }\end{array}$ & Less corruption \\
\hline
\end{tabular}

children's educational outcomes; as receiving monetary remittances enables people to afford such payments, remittances would be associated with greater corruption in the public education sector.

At the same time, remittances may enable people to consume private sector alternatives to publicly provided goods, if such alternatives exist (e.g., private education or medical treatment). ${ }^{6}$ While the theoretical framework of Abdih et al. (2012) predicts that such shifts towards private goods will make authorities less accountable and eventually make corruption more widespread at the country level, the incidence of bribery for remittancereceiving households may instead go down (substitution effect).

These mixed theoretical predictions find reflection in the ambiguous empirical evidence on the effects of remittances on corruption. For example, in support of their theoretical model, Abdih et al. (2012) find that, in a cross-section of 111 countries, higher ratios of monetary remittances to GDP lead to less control of corruption, government effectiveness and rule of law. A similar conclusion is obtained by Berdiev et al. (2013), who study country-level effects of monetary remittances on corruption in a panel (1986-2010) of 111 countries. Contrasting evidence is provided by Tyburski (2012), who finds that, in 2001-2007, the Mexican states receiving relatively more remittances witnessed downward corruption trends. Among the possible reasons, Tyburski mentions the power of remittances to reduce households' dependence on state programs and clientelism, which encourages voting for opposition parties and increases government accountability. Finally, in an empirical study that is most closely related to ours, Höckel et al. (2015) show that parental migration leads to a reduction in informal payments to school teachers in Moldova, which the authors explain with the migration-induced change in corruption norms at the household level (value transfer effect).

Table 1 summarizes channels through which migration may affect corruption at the household level. ${ }^{7}$ Note that it may not always be possible to fully disentangle these channels in an empirical analysis. For example, to test the value transfer channel, one needs information on household-level corruption outcomes (e.g., paying bribes or attitudes

\footnotetext{
${ }^{6}$ Some public services are unlikely to have private service alternatives. For example, when starting a new business or buying property, one needs to contact public officials to comply with documentary requirements.

${ }^{7}$ The exit and voice model is not included here as it draws on country level- rather than individual- or household-level channels.
} 
towards corruption), whether households have a family member abroad, as well as on the relative prevalence of corruption at home and in the migrant destination country. In addition, if information is available on whether households receive remittances, one can test for the communication and conditionality effects, although differentiating between the two requires detailed (probably qualitative) information on how exactly value transfer is amplified by remittances. Information on the household-level remittance receipt and corruption outcomes would also allow testing for the income effect. Caution should be applied, however, as remittance recipient households generally are a subset of migrant households. This means that, if included in the analysis without the migration variable, the effect of remittances would capture the net effect of the value transfer, communication, conditionality and income. Finally, testing the substitution channel would require, at the very least, information on the frequency of contacting public officials.

\section{Context}

We focus on the region formerly known as Yugoslavia, which is particularly well-suited for our analysis. Both corruption and migration have been prominent experiences for the region's residents. The ex-Yugoslavian countries systematically have topped the charts of the worst corruption performers in Europe: for example, the 2015 Corruption Perception Index (ranging from 0, the most corrupt, to 100, the least corrupt) of Transparency International (Transparency International 2015) reports scores of 33 and 38 for Kosovo and Bosnia \& Herzegovina (the only other European countries with scores below 40 are Albania, Russia, Belarus and Ukraine). A large survey conducted in the Western Balkans in 2010 (United Nations Office on Drugs and Crime 2011) indicates that 17\% of the adult population in the region had direct or indirect exposure to bribery in the year prior to the survey.

In most countries of the former Yugoslavia, decades of emigration generated massive diasporas and large inflows of monetary remittances. Emigration has been a longue duree phenomenon in the region: large scale transoceanic out-migration to the United States, Canada, South America and Australia occurred at the end of the 19th and beginning of the 20th century, as well as in the interwar period (Brunnbauer 2009). A major post-WWII wave of migration was triggered in the 1960s, when the Yugoslavian government signed bilateral recruitment agreements with Germany, France, Austria, Switzerland, Sweden, Australia and other countries of the industrialised world (see column 1 of Table 2 for the distributions of migrants by country in 1971). The contracting of these 'guest worker' schemes was motivated, on the one hand, by the economic boom and growing demands for construction and manufacturing workers in the Western world and, on the other, by the surge in unemployment following Yugoslavia's market-oriented reforms in the 1960s. The Yugoslavian government actively supported emigration of workers, considering it a 'necessary evil' to alleviate labor market problems (Mlinaric 2009). Overall, 3.8\% of all Yugoslav citizens worked abroad in 1971 (Brunnbauer 2009).

The guest worker out-migration was assumed to be of a temporary nature. This, however, did not prove to be the case: when jobs dried up after the 1973 oil shock, many temporary migrants stayed in the host countries and migration continued in the form of family reunifications in the 1970s and 1980s (Zimmerman 1987). Migration became a mass phenomenon in Yugoslavia, engendering cultures of migration fuelled further by the consumerism launched by migrants' remittances (Brunnbauer 2009). Remittances continue 
Table 2 Distribution of Yugoslav migrants by destination, 1971 and 2010-2011 source Baucic (1973b); Gallup Balkan Monitor

\begin{tabular}{lcc}
\hline Country of destination & $1971^{\mathrm{a}}(\%)$ & $2010-2011^{\mathrm{b}}(\%)$ \\
\hline Germany & 61.2 & 37.3 \\
Austria & 12.3 & 12.1 \\
Australia & 6.0 & 6.6 \\
France & 5.5 & 5.3 \\
United States and Canada & 4.4 & 22.7 \\
Belgium, Netherlands, Luxemburg and Sweden & 3.5 & 10.8 \\
Switzerland & 3.2 & 13.2 \\
Italy & - & 7.5 \\
United Kingdom & - & 2.4 \\
\hline
\end{tabular}

\footnotetext{
a Share of all emigrants

b Share of households indicating that their relatives/friends live in a particular country (up to three destinations possible)
}

to be large: in 2014, migrant money transfers ranged from 8 to $16 \%$ of GDP in Bosnia and Herzegovina, Kosovo, Montenegro and Serbia (Source: World Bank Development Indicators 2012).

How do we expect the theoretical channels linking emigration and corruption to work in the post-Yugoslav context? First, given that most migrant destinations-both historical and contemporary-are developed Western countries that have lower levels of corruption relative to successor states of former Yugoslavia, any migration-induced transfer of corruption-related values, norms and practices should then result in a lesser proclivity for corrupt practices among migrant family members staying behind. Second, the literature that we surveyed does not reveal any specific features in the post-Yugoslav context that would block transmission along other channels described in Table 1. Monetary remittances could raise or lower corruption, depending on whether the income effect or the substitution effect dominates, as described in Table 1.

\section{Data, variables and estimation strategy}

\subsection{Data}

The quantitative analysis is based on the Gallup Balkan Monitor survey. The survey, best characterized as repeated cross-sections, was carried out in Albania, Bosnia and Herzegovina, Croatia, Kosovo, Macedonia (Former Yugoslav Republic of Macedonia)), Montenegro and Serbia in 2006, and annually from 2008 to 2011, by the international opinion poll agency, Gallup. Nationally representative samples consisted of approximately 1000 people interviewed in each country each year (further details on the survey design and implementation are provided in the Supplementary Information document). As our instrumental variable analysis uses data from the former Yugoslavian population census, we exclude Albania, which was not part of Yugoslavia, from our sample. We also exclude the years 2006, 2008 and 2009 from the analysis, as the key question on the actual bribe 
payment was not asked in these years. Our dataset thus covers six countries over two years and consists of just over 12,000 observations.

\subsection{Variables}

\subsubsection{Corruption-related variables}

A nested question is used to capture households' actual bribe-paying experiences. First, the respondents were asked whether, in the 12 months prior to the interview, they or anyone in their household had contact with any of the following public institutions/organizations: (1) education system, (2) judiciary, (3) medical services, (4) police, (5) registry and permit services, (6) utilities, (7) tax revenue, (8) land services and (9) customs. If the answer to the contact question was affirmative, the respondents were then asked, with reference to each institution, whether they or anyone in their household "paid a bribe in any form". Based on this information, we construct two dichotomous variables. First, the variable contacted public official is equal to 1 if, in the 12 months prior to the interview, the respondent or someone in the household contacted at least one type of public official, and 0 if there had been no contact. Second, the variable paid a bribe is equal to 1 if a bribe was paid to at least one type of public official, and 0 if at least one type of official was contacted, but no bribe was paid; this variable is based on the sub-sample of respondents who had contact with at least one type of public official. Although we are most interested in how migration affects the likelihood of paying bribes, we also want to check how migration affects the likelihood of contacting public officials, as contact increases bribery indirectly (Ivlevs and Hinks 2015a).

The respondents also were asked: "During the past year, has any government official or a civil servant, for instance a customs officer, police officer or inspector, asked you or expected you to pay a bribe for his service?" Based on this question, we construct a dichotomous variable was asked for bribe (this variable is based on the full sample of respondents). Note that an affirmative answer to this question does not necessarily mean that the bribe actually was paid.

Finally, to capture the respondents' attitudes towards corruption, we rely on a set of questions wherein the respondents were asked to provide their opinions on four types of behavior: (1) offering some money/gifts to a public official to speed up administrative procedures; (2) offering some money/gifts to a teacher to help one's child to pass an exam; (3) a public official taking money/gifts from clients to top up a low salary; (4) a teacher asking for money/gifts to help one's child pass an exam. Respondents chose from a menu of four possible answers to each question: "it is always unacceptable", "it is slightly unacceptable", "it is sometimes acceptable" and "it is always acceptable". Assigning these answers values $1-4$, we use principal component analysis to create an index of acceptability of bribe offering (behaviors 1 and 2) and an index of acceptability of bribe taking (behaviors 3 and 4 ). ${ }^{8}$ In this way, we capture both the 'give' and 'take' of corrupt interchanges as reflected in respondents' attitudes.

\footnotetext{
8 The eigenvalues of the first principal component for the two indexes are 1.71 and 1.79 , respectively. Note that our results remain unchanged if the two indexes are created by summing up the values of the input variables.
} 


\subsubsection{Migration-related variables}

To construct our migration-related variables, we use two of the survey's questions. First, "In the past 12 months, did this household receive help in the form of money or goods from another individual”, with possible answers (1) Yes, living in this country; (2) Yes, living in another country; (3) Yes, both (living in this or another country); and (4) No. We combine the second and third answers to this question to construct a dichotomous variable, remittances. Second, the respondents were asked, "Do you have relatives or friends who are living in another country whom you can count on to help you when you need them, or not?" This question captures foreign networks. An affirmative answer to it would imply that a respondent maintains a minimum level of communication with the relative/friend abroad, which, arguably, is a necessary condition for an efficient transfer of values, norms and practices from migrants to those staying behind. ${ }^{9}$

We also have information on the countries where the respondents' friends and relatives reside. The majority of them are Western industrialized economies (see column 2 of Table 2); we also observe a close correspondence between these countries and the destinations of the Yugoslav workers in 1971. However, in $11 \%$ of cases, the destinations represent the successor states of the former Yugoslavia. We refrain from identifying relatives and friends living in those countries as foreign networks, as they are likely to originate from past internal migration, formation and shifting of national borders after the breakdown of Yugoslavia, as well as the refugee flows of the 1990s and 2000s. ${ }^{10}$ Thus, our focus is on international migrant networks, which, geographically, extend beyond the borders of the former Yugoslavia. We construct a dichotomous variable non-recipient migrant household, which is equal to 1 if a respondent has a relative/friend abroad but does not receive remittances, and 0 otherwise (remittance-recipient or non-migrant household). We, therefore, have two variables capturing migrant households with and without incoming monetary remittances. ${ }^{11}$

\subsubsection{Socio-demographic characteristics and other controls}

Following the literature on the micro-determinants of bribery (see, e.g., Ivlevs and Hinks 2015a, b), in all regressions we include the following sociodemographic controls: age (measured in years, continuous), and dichotomous variables for gender, education level (primary, secondary, tertiary), five within-country income quintiles, four degrees of urbanisation (rural area/farm, village/small town, suburb of a large city, large city), and main religious affiliations (Orthodox, Catholic, Muslim, other). Country/region fixed effects (dichotomous variables for Croatia, Bosnia and Herzegovina, Serbia, Macedonia,

\footnotetext{
9 Note that the way in which the networks' question is phrased probably overestimates the effects of migration relative to a more standard definition of foreign networks relying on any relatives or friends abroad.

${ }^{10}$ For the purposes of this paper, respondents with networks in former Yugoslavia are considered nonmigrant households and they are not dropped from the analysis.

11 An alternative is to use an 'inclusive' dummy for migrant households regardless of whether they receive remittances and a dummy for remittance receipt. Such a choice of migration dummies would work for the non-IV estimations; we have done it as a robustness check and the results are in line with those presented in Table 3. However, the estimation of the IV models with two endogenous regressors would necessitate at least two instruments. With only one convincing instrument at hand, we choose to use the non-overlapping migration dummies, which help us identify different types of migrant households and can be included in the IV models separately.
} 
Table 3 Relatives abroad, remittances, and corruption experience and attitudes: conditional correlations

\begin{tabular}{|c|c|c|c|c|c|}
\hline & $\begin{array}{l}\text { Contacted } \\
\text { public official } \\
\text { Probit } \\
\text { (1) }\end{array}$ & $\begin{array}{l}\text { Paid a } \\
\text { bribe } \\
\text { Probit } \\
\text { (2) }\end{array}$ & $\begin{array}{l}\text { Was asked } \\
\text { for bribe } \\
\text { Probit } \\
\text { (3) }\end{array}$ & $\begin{array}{l}\text { Accept bribe } \\
\text { offering } \\
\text { OLS } \\
\text { (4) }\end{array}$ & $\begin{array}{l}\text { Accept bribe taking } \\
\text { by officials } \\
\text { OLS } \\
\text { (5) }\end{array}$ \\
\hline $\begin{array}{l}\text { Relatives abroad, no } \\
\text { remittances }\end{array}$ & $\begin{array}{l}0.237 * * * \\
(0.054)\end{array}$ & $\begin{array}{l}0.059 \\
(0.063)\end{array}$ & $\begin{array}{l}0.224 * * * \\
(0.068)\end{array}$ & $\begin{array}{l}-0.047 \\
(0.055)\end{array}$ & $\begin{array}{l}-0.061 \\
(0.049)\end{array}$ \\
\hline Remittances & $\begin{array}{l}0.237 * * * \\
(0.082)\end{array}$ & $\begin{array}{l}0.112 \\
(0.075)\end{array}$ & $\begin{array}{l}0.333 * * * \\
(0.075)\end{array}$ & $\begin{array}{l}0.060 \\
(0.093)\end{array}$ & $\begin{array}{l}0.008 \\
(0.084)\end{array}$ \\
\hline $\begin{array}{l}\text { Socio-demographic } \\
\text { controls }\end{array}$ & Yes & Yes & Yes & Yes & Yes \\
\hline $\begin{array}{l}\text { Country/region fixed } \\
\text { effects }\end{array}$ & Yes & Yes & Yes & Yes & Yes \\
\hline Year dummy (2011) & Yes & Yes & Yes & Yes & Yes \\
\hline Observations & 12,084 & 8771 & 12,084 & 11,743 & 11,678 \\
\hline $\begin{array}{c}\text { Prob }>\mathrm{Chi}^{2} / \\
\text { Prob }>\mathrm{F}\end{array}$ & 0.000 & 0.000 & 0.000 & 0.000 & 0.000 \\
\hline
\end{tabular}

Kosovo, Montenegro, as well as for the Serbian region of Vojvodina) are entered to control for unobserved country-level factors (time-invariant between 2010 and 2011), which could be correlated both with migration intensity and corruption outcomes. ${ }^{12}$ The definitions and summary statistics of all variables can be found in the Supplementary Information document.

\subsection{Estimation strategy and instrument}

Our objective is to estimate the following model:

$$
\text { CORRUPTION }_{i j}=\alpha+\beta M I G R A T I O N_{i j}+\gamma X_{i j}^{\prime}+\pi_{j}+\text { Year } \_2011+u_{i j},
$$

where, for individual $i$ living in country $j$, the dependent variable CORRUPTION stands, in alternative specifications, for the variables capturing bribery experience and attitudes towards corruption, the explanatory variable MIGRATION stands for migration-related variables (remittance-recipient and non-recipient migrant households). Vector $X$ includes sociodemographic controls, the $\pi_{j}$ are country/region fixed effects, Year_2011 is a dichotomous variable for year $2011,{ }^{13}$ and $u_{i j}$ is the error term.

Given the binary nature of the corruption related variables paid a bribe, contacted public official and was asked for bribe, we estimate the models that use them as dependent variables with binary probit. The models explaining attitudes to corruption are estimated with OLS. We first report conditional correlations, i.e., the results of the models that do not

\footnotetext{
12 Importantly, the inclusion of the country/region dummies automatically controls for having a historical connection to the Austro-Hungarian empire (Croatia, Bosnia and Herzegovina and Vojvodina once were part of the empire), which might be driving both present-day corruption (Becker et al. 2016) and migrationthrough a particularly favorable emigration regime that citizens of the Austro-Hungarian empire enjoyed at the turn of the 20th century relative to people in other parts of Yugoslavia.

13 Recall that our data come from two repeated cross-sectional surveys conducted in 2010 and 2011.
} 
address the potential endogeneity of migration and remittances. We then use the instrumental variable (IV) approach to deal with potential endogeneity and determine the effect of migration on corruption experiences and attitudes.

The endogeneity of migration could arise from reverse-causality, if corruption at home pushes people abroad or if people emigrate with an intent of accumulating resources toward engaging in corruption in the home country at a later stage (e.g., paying a doctor for major surgery or accelerating the licencing process when starting a new business). The very process of preparing to emigrate can make people more prone to corruption so as to secure speedy delivery of passports, visas, certificates of health and so on. If such sources of endogeneity are present, we would expect the effect of emigration on corruption, estimated in correlational analysis, to be biased upward. In addition, unobserved characteristics of people (and/or households) may exist that are correlated with both the willingness to migrate and the propensity to bribe public officials. This could produce an upward or downward bias in the correlational analysis, depending on the proclivity to corruption of emigrants and their household members.

Following Böhme et al. (2015) and Höckel et al. (2015), we use the interaction between historical municipality-level migration networks and the economic conditions at the main migrant destination countries (municipality-level variable) as an instrument for emigration at the household level. Specifically, for each municipality, we take the summation of the GDP growth rates of major migrant destinations weighted by the pre-existing migrant networks (the number of migrants relative to municipality population) in those destinations. Formally, the instrument can be expressed as follows:

$$
\text { Migration-Growth-Interaction }_{c}=\sum_{j} \frac{\text { Migrants }_{c, j, 1971}}{\text { Population }_{c, 1971}} \times\left(\frac{1}{5} \sum_{\tau} \text { GDPgrowth }_{\tau, j}\right),
$$

where $c$ is municipality, $j=1,2, \ldots, J$ is the migration destination country, and $\tau=2001$, $\ldots, 2005$ are the five years over which the destination countries' growth rates will be calculated. The choice of the 2001-2005 period for the destination countries' growth rates, and of the year 1971 for pre-existing migrant networks, is explained in more detail below. Note that the same time horizon for growth rates (2001-2005) is used to construct the instrument for respondents interviewed in both 2010 and 2011, and, as such, the instrument is not time-varying.

We expect the municipality-level networks-destination-growth interaction to predict current emigration in two ways. First, pre-existing migrant networks are known to be powerful predictors of the emigration decision. Existing migrant networks reduce migration costs for subsequent migrants by conveying information about the destination country prior to the move, by providing financial assistance, facilitating employment and accommodation, and giving support in various forms after the move (see, e.g., Massey et al. 1998). It also has been shown that networks played a crucial role in explaining successive waves of Yugoslavian out-migration (Brunnbauer 2009). Second, high GDP growth rates in the destination countries, and favorable economic conditions more generally, imply better job opportunities, which act as a pull factor for prospective migrants (Antman 2011). The network component of the instrument reinforces the destinations' growth component: the larger the network is, the more existing migrants will be able to convey information, particularly information about favorable economic conditions, about the destination and help migrants upon arrival.

The information on the historical migrant networks comes from the 1971 Population Census of Yugoslavia (Baucic 1973b). During this census, information on the number of 
migrants, as well as migrants' gender, age, education and, crucially for this study, destination countries, ${ }^{14}$ was supplied by migrants' family members and, when the whole household had emigrated, by neighbors. Only the records on "Yugoslav workers temporarily employed abroad" were collected by the census: the data thus capture only guest worker migration flows, which started in the mid-1960s and hit their peak in 1971, and underestimate the total stock of Yugoslav emigrants at that time. Importantly for our study, all information on migrant stocks is available at municipality/commune level.

We represent economic conditions at the migrant destinations by the average of the destination countries' GDP growth rates in the 2001-to-2005 time-span. That period precedes the advent of the global recession and is characterized by strong economic growth across most of the world, sending a strong signal to prospective migrants. Our IV analysis will, thus, capture the effects of migration and remittances that are driven by the relatively recent economic developments in historical migrant destinations.

The exogeneity of the instrument has to be considered from the point of view of both its network and its GDP growth component. One can convincingly rule out any direct effect of the destination countries' GDP growth rates on corruption outcomes in the migrants' countries of origin: it is difficult to think of channels through which economic conditions in foreign countries would lead to differential corruption outcomes within a migrant's source country-apart from the effect running through migration. The possibility that historical migration networks, the other component of the instrument, might be directly related to home-country corruption invites some discussion. ${ }^{15}$ For example, it is not inconceivable that local guest worker emigration in the 1960s and 1970s might have been driven by the local-level corruption at that time. If such local corruption persisted, the historical migration networks may be directly related to differences in corruption incidence today. An ideal solution would be to control for the local-level prevalence of corruption in the Yugoslavia of the 1960s and 1970s. Such data, however, are not available. Instead, we use the 1971 municipality-level illiteracy rate, sourced from the 1971 Yugoslav Population Census, as a proxy for local-level development and corruption in both stages of the IV estimation. $^{16}$

To validate the network component of our instrument further, it is useful to outline the actual reasons behind the local-level variation in the early 1970s' migration rates. First, the variation can be traced back to the different regional rates of migration that the countries of ex-Yugoslavia experienced at the turn of the 20th century and the interwar period (Baucic 1973a; Brunnbauer 2009). This, for example, explains why certain regions of Croatia and the Dalmatian coast of Bosnia and Herzegovina were the first to embrace guest-worker emigration opportunities, exhibiting the highest municipal rates of emigration. Prior to WWI, those regions were part of the Austro-Hungarian Empire (which had a particularly favorable emigration regime), had close access to seaports and, in addition, were subject to agricultural shocks (e.g., the Phylloxerra epidemics that destroyed much of the profitable Dalmatian wine industry (Mlinaric 2009; Brunnbauer 2009)). Those factors

\footnotetext{
14 The data are available for the major migrant destinations: Austria; Australia; Canada and the United States (jointly); France; Sweden and the Benelux countries (jointly); Switzerland; and West Germany.

15 This said, historical region-level migration rates have been used as stand-alone instruments for current migration in Mexico (McKenzie and Rapoport 2011; Pfutze 2012).

${ }^{16}$ It is noteworthy that the illiteracy rate tends to be insignificant in the first-stage regression, which might suggest that the local-level development and corruption were not principal drivers of the guest-worker emigration in ex-Yugoslavia. Our overall results remain unchanged if the illiteracy rate is excluded from the analysis. See also the Supplementary Information for correlations between current corruption outcomes and 1971 local-level emigration (including by destination) as well as current emigration at the local level.
} 
contributed to early out-migrations from the region and to the development of strong cultures of migration that have persisted.

The demand-driven nature of bilateral recruiting and guest worker migration programs is another reason why emigration rates exhibited regional variation. Representatives of host countries' manufacturing companies recruited workers directly, in some cases through the Yugoslav state employment agencies. However, the distribution of foreign recruiters within Yugoslavia was uneven. For example, manufacturers from West Germany, the most important destination of Yugoslav migrants, recruited workers from specific regions in Yugoslavia, because they had good experience with workers from these regions (Novinscak 2009).

It should also be stressed that the early guest-worker out-migration from Yugoslavia clearly was considered, by both migrants and the ruling elites, to be temporary. Migrantsoften young, low-skilled men with agricultural backgrounds-went abroad to earn money that they planned to invest back home in building/extending houses or buying land and agricultural machinery (Pichler 2009; Novinscak 2009). Property sales at home were rare, and the immediate family (spouse, children) typically were left behind, confirming return intentions of the first guest-worker migrants (Brunnbauer 2009). This, again, does not support a possible conjecture that the guest worker migration was driven by the extent of local corruption.

Overall, the context and demand-side-managed nature of the guest worker out-migration in former Yugoslavia, coupled with the use of within-region variation in migration rates and a control for local-level development at the time of migration, render it very unlikely that the variations in historical local-level migration rates are related directly to today's local-level corruption. This makes us confident that the network component of the network-growth interaction instrument is exogenous to present-day corruption.

\section{Results}

\subsection{Correlational evidence}

Table 3 reports the results of the bribery experience and corruption attitude models, which do not address endogeneity. Here and in what follows, we report only the results for the variables of interest; full econometric output and a commentary on the coefficients of control variables can be found in the Supplementary Information document. A strong positive association exists between being a migrant household and having contacted a public official in the past 12 months (specification 1); in terms of (average) marginal effects, members of both remittance-recipient and non-recipient migrant households are 7.4 percentage points more likely to have contacted officials relative to people in nonmigrant households. Among those who contacted public officials, the coefficients on the two migration variables are insignificant-migrant households are as likely to pay bribes as non-migrant households (specification 2). A strong positive association also exists between having relatives abroad and having been asked for a bribe by a public official: the marginal effects are $3.3 \%$ for non-recipient migrant households and $4.9 \%$ for households receiving remittances (specification 3); note, however, that the difference between the estimated coefficients for the two groups is statistically insignificant (Prob $>\mathrm{Chi}^{2}=0.105$ ). Concerning the attitudes towards bribery (specifications 4 and 5), the associations between the 
Table 4 Relatives abroad, remittances, and bribery experience: IV probit results

\begin{tabular}{|c|c|c|c|c|c|c|}
\hline & $\begin{array}{l}\text { Contacted } \\
\text { public official } \\
\text { (1) }\end{array}$ & $\begin{array}{l}\text { Contacted } \\
\text { public official } \\
\text { (2) }\end{array}$ & $\begin{array}{l}\text { Paid a } \\
\text { bribe } \\
\text { (3) }\end{array}$ & $\begin{array}{l}\text { Paid a } \\
\text { bribe } \\
\text { (4) }\end{array}$ & $\begin{array}{l}\text { Was asked } \\
\text { for bribe } \\
\text { (5) }\end{array}$ & $\begin{array}{l}\text { Was asked } \\
\text { for bribe } \\
\text { (6) }\end{array}$ \\
\hline $\begin{array}{l}\text { Relatives abroad, } \\
\text { no remittances }\end{array}$ & $\begin{array}{l}0.401 \\
(2.274)\end{array}$ & - & $\begin{array}{l}-1.409 * * \\
(0.632)\end{array}$ & - & $\begin{array}{l}-1.763^{* * * *} \\
(0.481)\end{array}$ & - \\
\hline Remittances & - & $\begin{array}{l}0.677 \\
(2.372)\end{array}$ & - & $\begin{array}{l}-1.686^{* * *} \\
(0.744)\end{array}$ & - & $\begin{array}{l}-0.655 \\
(1.911)\end{array}$ \\
\hline $\begin{array}{l}\text { Socio- } \\
\text { demographic } \\
\text { controls }\end{array}$ & Yes & Yes & Yes & Yes & Yes & Yes \\
\hline $\begin{array}{l}\text { Country/region } \\
\text { fixed effects }\end{array}$ & Yes & Yes & Yes & Yes & Yes & Yes \\
\hline $\begin{array}{l}\text { Year dummy } \\
\text { (2011) }\end{array}$ & Yes & Yes & Yes & Yes & Yes & Yes \\
\hline \multicolumn{7}{|c|}{ Instrument (Network-growth interaction) } \\
\hline $\begin{array}{l}\text { First-stage } \\
\text { coefficient }\end{array}$ & $0.643 * * *$ & $0.700 * * *$ & $0.713 * * *$ & $0.829 * * *$ & $0.643 * * *$ & $0.700 * * *$ \\
\hline $\begin{array}{l}\text { F test of } \\
\text { excluded } \\
\text { instrument }\end{array}$ & 16.68 & 16.20 & 20.91 & 24.00 & 16.68 & 16.20 \\
\hline Observations & 10,788 & 9621 & 7803 & 6871 & 10,788 & 9621 \\
\hline Prob $>\mathrm{Chi}^{2}$ & 0.000 & 0.000 & 0.000 & 0.000 & 0.000 & 0.000 \\
\hline
\end{tabular}

*** $p<0.01$; ** $p<0.05$; * $p<0.1$, robust standard errors, clustered at the municipality level, in parentheses. Only respondents who had a contact with public officials are included in specifications 3 and 4 . See Supplementary Information for complete econometric output

migration-related variables, on the one hand, and accepting bribe offers and bribe-taking behavior, on the other, are statistically insignificant. ${ }^{17}$

\subsection{Instrumental variable results}

Having one instrument (network-growth interaction) for both remittance-recipient and nonrecipient migrant households is not conducive to performing IV estimations that jointly include two endogenous regressors. Instead, we run separate IV estimations for recipientand non-recipient migrant households. To make sure that the effect of these variables is obtained by comparing migrant to non-migrant households, the models estimating the effect of receiving remittances exclude migrant households not receiving remittances, and the models estimating the effect of being a non-recipient migrant household exclude remittance receivers. This procedure also ensures that the reference group (non-migrant households) is the same in the non-IV and IV estimations, allowing a comparison of results.

The results of IV estimations for the bribery experience and attitudes models are shown in Tables 4 and 5. The results suggest that the instrument performs well in the first stage:

\footnotetext{
${ }_{17}$ Given that the results presented in Table 3 are likely to be correlated with each other, we have estimated models 2 and 3 with a bivariate probit and models 4 and 5 with the seemingly unrelated regressions (SUR). The results of these estimations are consistent with those presented in Table 3.
} 
Table 5 Relatives abroad, remittances, and attitudes towards bribery: 2SLS results

\begin{tabular}{lllll}
\hline & $\begin{array}{l}\text { Accept bribe } \\
\text { offering } \\
(1)\end{array}$ & $\begin{array}{l}\text { Accept bribe } \\
\text { offering } \\
(2)\end{array}$ & $\begin{array}{l}\text { Accept bribe taking } \\
\text { by officials } \\
(3)\end{array}$ & $\begin{array}{l}\text { Accept bribe taking } \\
\text { by officials } \\
(4)\end{array}$ \\
\hline $\begin{array}{l}\text { Relatives abroad, no } \\
\text { remittances }\end{array}$ & -0.878 & - & $-2.789 * * *$ & - \\
$\begin{array}{l}\text { Remittances } \\
(1.074)\end{array}$ & - & -1.619 & - & $\begin{array}{l}(1.037) \\
(1.058)\end{array}$ \\
$\begin{array}{llll}\text { Socio-demographic } \\
\text { controls }\end{array}$ & Yes & Yes & Yes & $\begin{array}{l}-3.091^{* *} \\
(1.286)\end{array}$ \\
$\begin{array}{l}\text { Country/region fixed } \\
\text { effects }\end{array}$ & Yes & Yes & Yes & Yes \\
$\begin{array}{l}\text { Year dummy (2011) } \\
\text { Instrument (Network-growth interaction) }\end{array}$ & Yes & Yes & Yes & Yes \\
$\begin{array}{l}\text { First-stage coefficient } \\
\text { F test of excluded }\end{array}$ & $0.644^{* * *}$ & $0.711^{* * *}$ & $0.651^{* * *}$ & Yes \\
instrument & 16.87 & 17.27 & 17.20 & $0.716^{* * *}$ \\
$\begin{array}{l}\text { Observations } \\
\text { Prob }>\text { F }\end{array}$ & 10,482 & 9360 & 10,426 & 17.38 \\
\hline
\end{tabular}

*** $p<0.01$; ** $p<0.05$; $p<0.1$, robust standard errors, clustered at the municipality level, used to calculate regressors' level if significance. See Supplementary Information for complete econometric output

the network-growth interaction instrument is a positive and significant predictor of being both a remittance-recipient and non-recipient migrant household (complete first-stage results can be found in Supplementary Information). The value of the F-test on the excluded instrument, performed after the first-stage estimation, ${ }^{18}$ ranges from 16 to 24 , depending on the sample. Values in this range exceed the "rule of thumb" threshold of 10 , which can be used to assess weak identification in IV models with clustered standard errors (Baum et al. 2007). This estimate indicates that the instrument is relevant and the estimations do not suffer from weak identification.

Specifications (1) and (2) of Table 4 report the second-stage results of the IV probit models, estimating the effect of out-migration on contacting public officials. The coefficients of both remittance-recipient and non-recipient migrant households are statistically insignificant in the contact model, meaning that out-migration has no effect on the likelihood of contacting public officials. Conditional on contacting public officials, migration reduces the likelihood of bribe payment (specifications 3 and 4): the coefficients on both remittance-recipient households and non-recipient migrant households are negative and significant at the $5 \%$ level. In terms of marginal effects, having friends or relatives abroad who do not send remittances back home reduces the likelihood of bribe payments by 34 percentage points, and receiving remittances reduces the likelihood of bribe payments by 40 percentage points. We are cautious about claiming that the estimates for the two migrant

\footnotetext{
18 In the models with continuous dependent variables (acceptance of bribe offering and bribe taking), that we estimate with 2SLS (ivreg2 in Stata), the F-test on the excluded instrument corresponds to the Kleibergen-Paap test of weak identification. In the models with binary dependent variables (contacted public official, paid a bribe, was asked for bribe), that we estimate with the IV probit (ivprobit in Stata), the F-test on the excluded instrument is not routinely available, which is why we perform it ourselves after running the first-stage regressions.
} 
household groups are different, as the 95\% confidence intervals of the estimated coefficients overlap substantially. ${ }^{19}$ Finally, specifications 5 and 6 suggest that having friends or relatives abroad who do not send remittances reduces the likelihood of being asked for a bribe by a public official by 48 percentage points, while the coefficient for remittance recipients is negative but statistically insignificant.

The results of the IV estimations for the corruption attitudes models are shown in Table 5. The estimates of the migration-related variables are negative in all cases, but statistically significant only for attitudes towards public officials' bribe taking. This result implies that out-migration renders public officials' bribe taking behavior less acceptable, although it does not change the acceptability of bribe offering - a type of double standard. The results also show that migrant households that receive monetary remittances tend to be less tolerant of bribe solicitations than migrant households that do not receive remittances; that said, the $95 \%$ confidence intervals for the estimated coefficients have a substantial overlap $[(-4.822,-0.756)$ and $(-5.611,-0.570)$ for specifications 3 and 4$]$, meaning that the difference between them may be zero in the statistical sense.

Finally, our results hold up to several robustness and sensitivity checks (including alternative time spans of host country growth rates for the instrument and variation in the corruption levels in migrant destination countries). A summary can be found the Supplementary Information document.

\subsection{Discussion}

The results of our instrumental-variable analysis suggest that, for those staying behind, emigration of friends and relatives has the following effects: (1) it reduces the likelihood of bribing public officials; (2) it renders bribe taking behavior by public officials less acceptable; (3) it reduces the likelihood of being asked for bribes by public officials.

Findings (1) and (2) can be interpreted as supporting the hypothesis that migrants transfer norms and practices across borders. As the principal destinations of migrants from the former Yugoslav region are industrialized market economies with relatively low levels of corruption, norms and practices that are less tolerant of bribery and corruption are, in this interpretation, transmitted through migration. This result lends support to the Levitt (1998) concept of social remittances, corroborates and extends the household-level evidence that migration reduces informal payments in the public education sector (Höckel et al. 2015), complements country-level evidence that migration leads to more control of corruption (Beine and Sekkat 2013), and aligns with the broader literature on the effects of migration on institutions.

Concerning monetary remittances, we find that both remittance-recipient and non-recipient migrant households are less likely to pay bribes and consider bribe taking behavior by public officials less acceptable. The estimated coefficients for the two groups are similar in size, which provides little support for the conjecture that migrant money enables people to offer bribes to public officials in order to get a quicker and better service, as well as for the conjectures that monetary remittances amplify the value transfer effect through communication and conditionality. Focusing on bribe solicitations paints a slightly different picture: having a migrant friend or relative who does not send remittances home reduces the likelihood of being asked for a bribe by a public official, but receiving remittances

\footnotetext{
19 The $95 \%$ confidence intervals for the coefficients of the variables of interest are $(-2.647 ;-0.171)$ and $(-3.141 ;-0.228)$ in specifications 3 and 4 , respectively (Table 4). We compare confidence intervals here, as it is not straightforward to compare estimated coefficients from regressions based on different samples.
} 
counteracts this effect. Our interpretation is that corruption-prone public officials refrain from soliciting bribes from households with migrant connections, because they consider it too risky. Through the migration-induced value transfer, members of migrant households may be more likely to condemn and report bribe soliciting behavior by public officials. However, if a person is known to receive monetary remittances, s/he becomes a more attractive target for a public official, and the greater risk is accompanied by more lucrative prospects for monetary reward.

Next, the out-migration of friends and relatives and receiving monetary remittances makes the bribe-taking/soliciting behavior of public officials less acceptable. This finding aligns with the value transfer/social remittances hypothesis; in addition, remittance receivers could be less tolerant of bribe solicitations because they may feel they have more to lose than non-migrant households. Interestingly, our findings also suggest that neither emigration nor remittances have a significant effect on the acceptability of bribe-offering behavior by the users of public services. One possible explanation is that the transfer of norms and values applies primarily to the behavior of public officials rather than to public service users. This could be because migrants, immediately upon arrival in the host country, have to interact with public officials, and it is easier to internalize and transmit behavior standards that have been experienced directly. By contrast, the behavior of hostcountry public service users is more difficult to internalize, as the migrant typically is not privy to such interactions. Note, however, that without further information we cannot say with certainty what is driving the difference; therefore, the explanation presented here remains purely hypothetical.

Finally, our IV results also suggest that receiving monetary remittances does not reduce contact with public officials, countering the hypothesis that remittances encourage people to turn to the privately provided alternatives to public services (assuming that such alternatives exist). However, we also note a positive association between being a migrant household (with or without remittances) and having contacted a public official in the past 12 months; this may reflect the necessity to contact public officials whilst preparing for migration.

In several model specifications, our findings reveal differences in the results of the nonIV and IV estimations: regressions not accounting for endogeneity tend to overestimate the 'true' effect of emigration on corruption. Such an upward bias could be explained by reverse causality (migration that is driven by local-level corruption; households sending migrants abroad with the prospect of engaging in corrupt exchanges at a later stage; preparation for migration leading to more contacts with public officials and bribery) as well as by unobserved characteristics that make households both more likely to send a migrant abroad and be involved in corrupt exchanges. In addition, the difference between the nonIV and IV results could be explained partly by the fact that the instrument is defined at the locality level, while both the outcomes and the main regressors are individual-level variables.

It remains to mention some limitations and possible extensions of our analysis. First, we do not have information on the sizes of bribes and whether the amounts paid in bribes change over time. It is possible that, with greater emigration and pressure from migrants and their family members, corruption-prone public officials concentrate on a smaller number of households and ask for larger bribes (which would also reduce the likelihood of being caught). To test these conjectures, future work should use data from longitudinal surveys wherein respondents are asked about the amounts of money paid in bribes; more generally, longitudinal data would also help control for time-invariant household heterogeneity potentially affecting both emigration and corruption. 
Second, we have hypothesised that migrants transfer anti-corruption-related norms and practices to their family members back home and have provided quantitative results that are consistent with this hypothesis. However, the exact mechanisms behind such transfers, which could involve visits, return migration and correspondence, remain to be clarified. This issue is policy-relevant, as the authorities in migration-sending countries may wish to facilitate (or block) specific channels through which migration affects corruption. Qualitative research could provide more insights into how exactly institutional norms and practices are transferred from migrants to their family members back home.

Third, one could extend the theoretical framework by assuming that corrupt officials anticipate that migration will put pressure on them. If that is the case, the officials may try to limit migration by being less corrupt ${ }^{20}$ or, as mentioned in footnote 3 of this paper, by behaving strategically to influence migration. While it is beyond the scope of this paper to fully engage and test the predictions of such an extended model, future research, supported by suitable data, could provide answers on whether public officials pre-emptively respond to the anticipated threats of migration and how this modifies the emigration-corruption relationship.

\section{Conclusion}

The purpose of this paper was to investigate whether migration affects corruption in the migrants' countries of origin. Using data from the Gallup Balkan Monitor survey in instrumental variable analysis, we found that out-migration of family members or close friends reduces the likelihood of bribing public officials, makes the bribe-taking behavior of public officials less acceptable, and reduces the likelihood of being asked for a bribe by a public official. Receiving monetary remittances can counteract the beneficial effect of migration on corruption - this is the case with respect to the likelihood of being solicited for a bribe by a public official.

Our findings suggest that migration, through the cross-border transfer of norms and practices, contributes to socioeconomic development by reducing one of the world's biggest growth-retarding elements-corruption. This points in the direction of liberalizing travel and communication between migrants and their home countries to facilitate the transfer of normative intangibles (examples of policies that could be considered by decision makers in both destination and origin countries are visa-free travel, double citizenship and incentives for diasporas to interact with home communities). Our findings also identify a group of people-migrant households receiving remittances-that are particularly exposed to bribe solicitations and toward whom corruption prevention policies could be directed.

Acknowledgements We thank the editors, two anonymous referees, Ulf Brunnbauer, Anda David, Frederic Docquier, Richard Frensch, Audrey Lenoel, Chris Parsons, Francisco Requena-Silvente, Michail Veliziotis, seminar and conference participants at the Universities of Milan, Oxford, Paris, Regensburg, West of England, Columbia, Tsinghua and Indian Institute of Management Bangalore for many helpful comments and suggestions. Financial support from Østfold University College and the Institute for East and Southeast European Studies (IOS Regensburg) is gratefully acknowledged.

Open Access This article is distributed under the terms of the Creative Commons Attribution 4.0 International License (http://creativecommons.org/licenses/by/4.0/), which permits unrestricted use, distribution,

${ }^{20}$ See also Haupt and Peters (2003) for a similar argument in a theoretical framework linking labor mobility and interregional competition on public pensions. 
and reproduction in any medium, provided you give appropriate credit to the original author(s) and the source, provide a link to the Creative Commons license, and indicate if changes were made.

\section{References}

Abdih, Y., Chami, R., Dagher, J., \& Montiel, P. (2012). Remittances and institutions: Are remittances a curse? World Development, 40(4), 657-666.

Antman, F. (2011). The intergenerational effects of paternal migration on schooling and work: What can we learn from children's time allocations? Journal of Development Economics, 96(2), 200-208.

Barsbai, T., Rapoport, H., Steinmayr, A. and Trebesch, C. (2017). The effect of labor migration on the diffusion of democracy: Evidence from a former soviet republic. American Economic Journal: Applied Economics (forthcoming).

Batista, C., \& Vicente, P. (2011). Do migrants improve governance at home? Evidence from a voting experiment. World Bank Economic Review, 25(1), 77-104.

Baucic, I. (1973a). Yugoslavia as a country of emigration. Migrations méditerranéennes 22 (pp. 56-66). Paris: CIHEAM.

Baucic, I. (1973b). Radnici u inozemstvu prema popisu stanovništva Jugoslavije 1971 [Yugoslav workers abroad according to the 1971 Yugoslav census]. Zagreb: Institut za Geofrafiju Sveučilišta.

Baum, C., Schaffer, M., \& Stillman, S. (2007). Enhanced routines for instrumental variables/generalized method of moments estimation and testing. Stata Journal, 7(4), 465-506.

Becker, S. O., Boeckh, K., Hainz, C., \& Woessmann, L. (2016). The empire is dead, long live the empire! Long-run persistence of trust and corruption in the bureaucracy. The Economic Journal, 126(590), 40-74.

Beine, M., \& Sekkat, K. (2013). Skilled migration and the transfer of institutional norms. IZA Journal of Migration, 2, 9.

Beine, M., Docquier, F., \& Schiff, M. (2013). International migration, transfer of norms, and home country fertility. Canadian Journal of Economics, 46(4), 1406-1430.

Berdiev, A. N., Kim, Y., \& Chang, C. P. (2013). Remittances and corruption. Economics Letters, 118(1), $182-185$.

Bertoli, S., \& Marchetta, F. (2015). Bringing it all back home: Return migration and fertility choices. World Development, 65, 27-40.

Böhme, M. H., Persian, R., \& Stöhr, T. (2015). Alone but better off? Adult child migration and health of elderly parents in Moldova. Journal of Health Economics, 39, 211-227.

Bologna, J., \& Ross, A. (2015). Corruption and entrepreneurship: evidence from Brazilian municipalities. Public Choice, 165(1), 59-77.

Brunnbauer, U. (2009). Labour emigration from the Yugoslav region from the late 19th century until the end of socialism: Continuities and changes. In U. Brunnbauer (Ed.), Transnational societies, trans territorial politics. Migrations in the (post-)Yugoslav region, 19th-21st century. Munich: R. Oldenbourg Verlag.

Burgess, K. (2012). Migrants, remittances and politics: Loyalty and voice after exit. Fletcher Forum of World Affairs, 36(1), 43-55.

Chauvet, L., \& Mercier, M. (2014). Do return migrants transfer political norms to their origin country? Evidence from Mali. Journal of Comparative Economics, 42(3), 630-657.

Dimant, E., Krieger, T., \& Meierrieks, D. (2013). The effect of corruption on migration, 1985-2000. Applied Economics Letters, 20(13), 1270-1274.

Docquier, F., Lodigiani, E., Rapoport, H., \& Schiff, M. (2016). Emigration and democracy. Journal of Development Economics, 120, 209-223.

Dreher, A., \& Gassebner, M. (2013). Greasing the wheels? The impact of regulations and corruption on firm entry. Public Choice, 155, 413-432.

Haupt, A., \& Peters, W. (2003). Voting on public pensions with hands and feet. Economics of Governance, $4(1), 57-80$.

Hirschman, A. (1970). Exit, voice, loyalty responses to decline in firms, organizations, and states. Cambridge, MA: Harvard University Press.

Hladnik, M. (2009). From a dollar bill in an envelope to a petition to the White House: The significance of Slovenian migrants for those back home. In U. Brunnbauer (Ed.), Transnational societies, trans territorial politics. Migrations in the (post-)Yugoslav region, 19th-21st Century. Munich: R. Oldenbourg Verlag. 
Höckel, L., Santos Silva, M., and Stöhr, T. (2015). Can parental migration reduce petty corruption in education? Kiel Working Paper No. 2018, Kiel Institute for the World Economy.

Hoffmann, B. (2010). Bringing Hirschman back in: "exit", "voice", and "loyalty" in the politics of transnational migration. The Latin Americanist, 54(2), 57-73.

Ivlevs, A., \& Hinks, T. (2015a). Sample selection and bribing behaviour: Evidence from post-socialist countries and Western Europe. Journal of Economics and Statistics, 235(2), 139-167.

Ivlevs, A., \& Hinks, T. (2015b). Global economic crisis and corruption. Public Choice, 162(3-4), 425-445.

Johnson, N. D., LaFountain, C. L., \& Yamarik, S. (2011). Corruption is bad for growth (even in the United States). Public Choice, 147(3-4), 377-393.

Levitt, P. (1998). Social remittances: Migration driven local-level forms of cultural diffusion. International Migration Review, 32(4), 926-948.

Li, X., McHale, J., and Zhou, X. (2017). Does brain drain lead to institutional gain? The World Economy (forthcoming).

Mariani, F. (2007). Migration as an antidote to rent-seeking? Journal of Development Economics, 84(2), $609-630$.

Massey, S. D., Arango, J., Koucouci, A., Pelligrino, A., \& Taylor, E. (1998). Worlds in motion: Understanding international migration at the end of the millennium. Oxford: Oxford University Press.

McKenzie, D., \& Rapoport, H. (2011). Can migration reduce educational attainment? Evidence from Mexico. Journal of Population Economics, 24, 1331-1358.

Méon, P.-G., \& Sekkat, K. (2005). Does corruption grease or sand the wheels of growth? Public Choice, 122(1), 69-97.

Miletic, A. (2009). (Extra-)institutional practices, restrictions and corruption. Emigration policy in the Kingdom of Serbs, Croats, and Slovenes (1918-1928. In U. Brunnbauer (Ed.), Transnational societies, trans territorial politics. Migrations in the (post-)Yugoslav region, 19th-21st century. Munich: R. Oldenbourg Verlag.

Mlinaric, D. (2009). Emigration research in Croatia: An overview. In U. Brunnbauer (Ed.), Transnational societies, trans territorial politics. Migrations in the (post-)Yugoslav region, 19th-21st century. Munich: R. Oldenbourg Verlag.

Novinscak, K. (2009). The recruiting and sending of Yugoslav 'gastarbeiter' to Germany: Between socialist demands and economic needs. In U. Brunnbauer (Ed.), Transnational societies, trans territorial politics. Migrations in the (post-)Yugoslav region, 19th-21st century. Munich: R. Oldenbourg Verlag.

Pfutze, T. (2012). Does migration promote democratization? Evidence from the Mexican transition. Journal of Comparative Economics, 40(2), 159-175.

Phillips, D. L. (2012). Liberating Kosovo: Coercive diplomacy and U.S. intervention (p. 256). Cambridge: MIT Press.

Pichler, R. (2009). Migration, architecture and the imagination of home(land) An Albanian-Macedonian case study. In U. Brunnbauer (Ed.), Transnational societies, trans territorial politics Migrations in the (post-)Yugoslav region, 19th-21st century. Munich: R. Oldenbourg Verlag.

Poprawe, M. (2015). On the relationship between corruption and migration: Empirical evidence from a gravity model of migration. Public Choice, 3-4, 337-354.

Schneider, F. (2015). Does corruption promote emigration? IZA World of Labor 192.

Shain, Y., \& Barth, A. (2003). Diasporas and international relations theory. International Organization, 57(3), 449-479.

Transparency International (2015). Corruption Perception Index. https://www.transparency.org/cpi2015.

Tyburski, M. D. (2012). The resource curse reversed? Remittances and corruption in Mexico. International Studies Quarterly, 56, 339-350.

United Nations Office on Drugs and Crime. (2011). Corruption in the Western Balkans: Bribery as experienced by the population. Vienna: UNODC.

Varese, F. (2011). Mafias on the move: how organized crime conquers new territories. Princeton: Princeton University Press.

World Bank Development Indicators. (2012). The World Bank. http://data.worldbank.org/data-catalog/ world-development-indicators.

Zimmerman, W. (1987). Open borders, nonalignment, and the political evolution of Yugoslavia. Princeton: Princeton University Press. 